\title{
ALGORITHMS FOR SPLIT COMMON NULL POINT PROBLEM WITHOUT PRE-EXISTING ESTIMATION OF OPERATOR NORM
}

\author{
M. Dilshad, M. AKRAM AND IZHAR AHMAD
}

Abstract. The purpose of this paper is to present iterative methods to solve a split common null point problem in real Hilbert spaces such that the implementation of proposed iterative schemes do not require any pre-existing estimation of the norm of bounded linear operator. We give the weak and strong convergence of the proposed algorithms under some mild and standard assumptions in Hilbert spaces. A numerical example is also constructed to illustrate the algorithm for strong convergence.

Mathematics subject classification (2010): 49J40, 49J53, 47J20, 58A05.

Keywords and phrases: Split common null point problem, algorithm, operator norm, resolvent operator, convergence.

\section{REFERENCES}

[1] C. BYRne, Y. Censor, A. GibAli AND S. REICH, Weak and strong convergence of algorithms for split common null point problem, J. Nonlinear Convex Anal. 13, 759-775, 2012.

[2] H. H. BAUSChKe AND J. M. BorWeIn, On projection algorithm for solving convex feasilibility problems, SIAM Rev. 38, 367-426, 1996.

[3] Y. Censor And T. ElfVing, A multiprojection algorithm using Bregman projections in a product space, Numer Algor. 8 (2), 221-239, 1994.

[4] Y. Censor, A. Gibali And S. ReICH, The split variational inequality problem, The Technion Institute of Technology, Haifa, arXive:1009.3780, 2010.

[5] Y. Censor, A. Gibali And S. ReICH, Algorithms for the split variational inequality problem, Numer Algor. 59, 301-323, 2012.

[6] Y. Censor, T. Bortfeld, B. Martin And A. Trofimov, A unified approach for inversion problems in intensity-modulated radiation therapy, Phys. Med. Biol. 51, 2353-2365, 2006.

[7] Y. Censor, T. Elfving, N. Kopf AND T. BorTfELD, The multiple-sets split feasibility problem and its applications for inverse problems, Inverse Probl. 21, 2071-2084, 2005.

[8] M. Dilshad AND M. AKRAM, Split hierarchical monotone variational inclusion problem involving finite families of firmly nonexpansive mappings, J. Math. Anal., 8 (3), 148-156, 2017.

[9] A. Gibali, K.-H. KÜFER AND P. SÜss, Reformulating the Pascoletti-Serafini problem as a bi-level optimization problem, Contemp. Math. 636, 121-129, 2015.

[10] K. R. KAZMI AND, S. H. RizVI, An iterative method for split variational inclusion problem and fixed point problem for a nonexpansive mapping, Optim. Lett. 8 (3), 1113-1124, 2014.

[11] K. R. KAZMI, R. Ali AND M. FURKAN, Hybrid iterative method for split monotone variational inclusion problem and hierarchical fixed point problem for a finite family of nonexpansive mappings, Numer Algor. 79 (2), 499-527, 2018.

[12] L. Panisa, K. Anchalee And F. Ali, Algorithms for the common solution of the split variational inequality problems and fixed point problems with applications, J. Inequal. Appl. 2018 (1), https://doi.org/10.1186/s13660-018-1942-1.

[13] G. Lopoz, V. Martín-Márquez, F. WANG And H. K. XU, Solving the split feasilibility problem without knowledge of matrix norm, Inverse Prob. 28:085004, 2012.

[14] A. MoudAfI, Split monotone variational inclusions, J. Optim. Theory Appl. 150, 275-283, 2011. 
[15] Z. OPIAL, Weak covergence of the sequence of successive approximations of nonexpansive mappings, Bull. Amer. Math. Soc. 73, 591-597, 1976.

[16] Y. SHEHU AND F. U. OGBUISI, An iterative method for solving split monotone variational inclusion and fixed point problems, Rev. R. Acad. Cienc. Exactas F-is. Nat. Ser. A Math. 110 (2), 503-518, 2016.

[17] K. SIRIYAN AND K. ATID, Algorithm method for solving the split general system of variational inequalities problem and fixed point problem of nonexpansive mapping with application, Math. Meth. Appl. Sci. 41 (17), 2018, https : //doi.org/10.1002/mma.5240.

[18] K. Sitthithakerngkiet, J. Deepho, J. Martinez-Moreno and P. Kumam, Convergence analysis of a general iterative algorithm for finding a common solution of split variational inclusion and optimization problems, Numer Algor. 79 (3), 801-824, 2018.

[19] Y. TANG AND Y. J. CHO, Convergence theorems for common solutions of split variational inclusion and systems of equilibrium problems, Mathematics 7 (3), 2019, https://doi .org/10.3390/math7030255.

[20] F. WANG, A new iterative method for the split common fixed poin problem in Hilbert spaces, Optim. 66, 407-415, 2017.

[21] H. K. XU, Iterative algorithms for nonlinear operators, J. Lond. Math. Soc. 66, 240-256, 2002.

[22] Y. TANG AND A. GiBALI, New self-adaptive step size algorithms for solving split variational inclusion problems and its applications, Numer Algor. 2019, https://doi.org/10.1007/s11075-019-00683-0.

[23] S. WANG, X. LiU AND Y. S. AN, A new iterative algorithm for generalized split equilibrium in Hilbert spaces, Nonlinear Func. Anal. Appl. 22 (4) 911-924, 2017.

[24] M. YUKAWA, K. SLAVAKIS AND I. YAMADA, Learning based on splitting and adaptive projection subgradient method, IEICE Trans. Fund. E98-A(2), 456-466, 2010.

[25] C. ZHANG AND Z. XU, Explicit iterative algorithm for solving split variational inclusion and a fixed point problem for the infinite family of nonexpansive operators, Nonlinear Func. Anal. Appl. 21 (4) 669-683, 2016. 